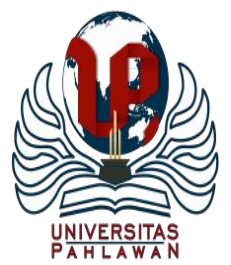

Edukatif : Jurnal Ilmu Pendidikan Volume 3 Nomor 5 Tahun 2021 Halm 2206 - 2216

EDUKATIF: JURNAL ILMU PENDIDIKAN

Research \& Learning in Education

https://edukatif.org/index.php/edukatif/index

\title{
Pendidikan Karakter Peduli Lingkungan Melalui Pembiasaan dan Pembudayaan di Sekolah Menengah Pertama
}

\author{
Lampola Sitorus $^{1 凶}$, Aldi Herindra Lasso ${ }^{2}$ \\ Universitas Kristen Satya Wacana, Salatiga, Indonesia ${ }^{1,2}$ \\ E-mail : 092019002@ student.uksw.edu ${ }^{1}$, aldi.lasso@uksw.edu $^{2}$
}

\begin{abstract}
Abstrak
Pendidikan karakter peduli lingkungan di sekolah formal merupakan salah satu strategi yang efektif untuk meningkatkan kepedulian masyarakat terhadap lingkungan yang mendukung pembangunan berkelanjutan. Tulisan ini mengkaji pengimplementasian pendidikan karakter peduli lingkungan di SMPN 2 Pangururan, Samosir, Sumatera Utara. Melalui pendekatan kualitatif, tulisan ini mengelaborasi peranan pembiasaan dan pembudayaan dalam penerapan pendidikan karakter peduli lingkungan. Hasil menunjukkan bahwa keteladanan yang dipelopori oleh pimpinan sekolah menjadi penggerak utama perubahan yang mendorong berjalannya program kepedulian lingkungan. Budaya sekolah yang terbentuk melalui progam ini berhasil membuat sekolah lebih sehat dan bersih dan warga sekolah lebih peduli terhadap lingkungan. Melihat besarnya peran keteladanan penting untuk memiliki pimpinan yang memiliki kapabilitas memadai agar mampu menginisiasi perubahan.
\end{abstract}

Kata Kunci: Pendidikan karakter; peduli lingkungan; keteladanan; Samosir.

\begin{abstract}
Character education for environmental care in formal schools is one of effective strategies to increase people's environmental awareness to promote sustainable development. This paper examines the implementation of environmental care character education at SMPN 2, Pangururan, Samosir. Through a qualitative approach, this paper elaborates the roles of habituation and cultural building in character education for environmental care. Findings show that examples initiated by headmaster encourage enactment of habituation and cultural building in character education programs. These programs have succeeded in changing the school environment into healthier and cleaner condition and making school residents more concerned about the environment. Viewing the significant role of examples, it is important to have leaders with adequate capabilities to initiate changes.
\end{abstract}

Keywords: Character education; environmental care; examples; Samosir.

Copyright (c) 2021 Lampola Sitorus, Aldi Herindra Lasso

$\triangle$ Corresponding author

Email :092019002@student.uksw.edu

DOI : https://doi.org/10.31004/edukatif.v3i5.755

ISSN 2656-8063 (Media Cetak)

ISSN 2656-8071 (Media Online) 


\section{PENDAHULUAN}

Kepedulian akan lingkungan memegang peranan penting dalam pembangunan karena keberlanjutan pembangunan itu sendiri tidak terlepas dari kondisi lingkungan. Namun pada kenyataannya, pembangunan sering kali berkontribusi besar dalam kerusakan lingkungan. Pembangunan umumnya mengakibatkan pertumbuhan laju penduduk yang seiring dengan laju peningkatan kebutuhan sehingga berdampak pada degradasi hutan dan lingkungan (Sarbi, 2018). Tidak hanya degradasi hutan akibat deforestasi demi tujuan pembukaan lahan, meningkatnya populasi ini juga berdampak pada pencemaran lingkungan (Zebua, 2017). Oleh karena itu, kondisi lingkungan sudah selayaknya menjadi perhatian dalam pembangunan berkelanjutan.

Pemeliharaan kondisi lingkungan dalam pembangunan berkelanjutan tidak terlepas dari peranan masyarakat didalamnya. Masyarakat memainkan peranan signifikan yang berpengaruh pada kegagalan atau keberhasilan pemeliharaan lingkungan. Dalam beberapa kajian mengenai pembangunan berkelanjutan, masyarakat sering dilihat sebagai penerima dampak pembangunan (Kurniawan, 2015; Lulus et al., 2015). Padahal apabila dikaji lebih dalam lagi, masyarakat memiliki potensi untuk berperan sebagai aktor yang dengan aktif dapat mempengaruhi keberlanjutan lingkungan. Masyarakat, melalui sikap dan kesadaran lingkungannya, telah tercatat sebagai pihak yang memberikan pengaruh signifikan dalam melawan pencemaran lingkungan (Chen, Huang and Lin, 2019). Oleh karena itu tulisan ini memandang bahwa masyarakat merupakan salah satu elemen kunci yang tidak dapat diabaikan dalam pembangunan berkelanjutan. Generasi muda merupakan representasi masyarakat yang potensial untuk berkontribusi dalam penciptaan masa depan yang lebih baik sesuai dengan tujuan pembangunan berkelanjutan. Guna mencapai masyarakat yang mampu mengurangi kerusakan lingkungan diperlukan suatu perubahan sikap dan perilaku masyarakat (dimana generasi muda termasuk didalamnya) untuk peduli pada lingkungan (Rokhman et al., 2014).

Berbicara mengenai perilaku manusia, pendidikan menjadi aspek yang paling penting karena dalam pendidikan terjadi pembinaan tingkah laku perbuatan agar manusia dapat berpikir, berperasaan dan bertindak lebih baik daripada sebelumnya (Juanda, 2010). Perubahan sikap dan perilaku yang peduli lingkungan dapat dibentuk dengan mengimplementasikan pendidikan karakter peduli lingkungan. Pendidikan karakter peduli lingkungan adalah suatu sikap yang dimiliki seseorang untuk memperbaiki dan mengelola lingkungan secara benar dan berkelanjutan sehingga ada manfaat yang berkesinambungan. Tujuan pengimplementasian pendidikan karakter ini adalah untuk melahirkan siswa yang memiliki sikap serta tindakan yang selalu berupaya mencegah kerusakan lingkungan dan berupaya memperbaiki kerusakan alam dapat terwujud (Purwanti, 2017). Sebagai intitusi pendidikan, sekolah menjadi tempat yang efektif dalam membentuk karakter peduli lingkungan dengan memberikan pendidikan lingkungan hidup (Ozsoy, Ertepinar and Saglam, 2012).

Pendidikan karakter peduli lingkungan sudah menjadi kewajiban setiap sekolah karena merupakan salah satu dari 18 karakter yg dirumuskan oleh pemerintah. Namun persoalan lingkungan akibat ulah manusia melahirkan pertanyaan sudah sejauh mana pendidikan karakter peduli lingkungan dilakukan melalui institusi pendidikan. Hal ini perlu ditelaah bersama dan penting untuk memberikan studi kasus mengenai implementasi pendidikan karakter peduli lingkungan yang berhasil membawa perubahan.

Implementasi pendidikan karakter dapat dilakukan melalui integrasi dalam mata pelajaran melalui Rencana Pelaksanaan Pembelajaran (RPP) dan silabus; integrasi dalam muatan lokal; kegiatan pengembangan diri berupa pembudayaan dan pembiasaan (mencakup pengkondisian, kegiatan rutin, kegiatan spontanitas, keteladanan, kegiatan terprogram); ektstrakurikuler; bimbingan konseling (Kementerian Pendidikan Nasional, 2011). Implementasi pendidikan karakter peduli lingkungan juga dapat dilakukan melalui pengitegrasian program kedalam proses pembelajaran melalui pengembangan silabus dan RPP, kegiatan pengembangan diri yang yang terdiri dari pembiasaan dan budaya sekolah (Purwanti, 2017). Dalam hal ini, kepala sekolah 


\section{Pendidikan Karakter Peduli Lingkungan Melalui Pembiasaan dan Pembudayaan di Sekolah Menengah Pertama - Lampola Sitorus, Aldi Herindra Lasso}

DOI: https://doi.org/10.31004/edukatif.v3i5.755

berperan menggerakkan, mengoordinasikan dan menyelaraskan semua sumber daya pendidikan termasuk hubungan sekolah dengan masyarakat (Mulyasa, 2018).

Penelitian-penelitian tentang pendidikan karakter peduli lingkungan banyak menekankan pentingnya aspek kognitif yang diterjemahkan dalam pengitegrasian program ke dalam mata pelajaran (Afandi, 2013; Khairoh, Rusilowati dan Nurhayati, 2014; Puspitasari, 2016; Miranto, 2017; Rezkita and Wardani, 2018; Widianingsih, 2019). Namun demikian, pengetahuan saja belum cukup menjamin berhasilnya pendidikan karakter peduli lingkungan. Tanpa perubahan sikap, pengetahuan peduli lingkungan hanya akan menjadi pengetahuan yang penerapannya tidak berkelanjutan. Pendidikan karakter peduli lingkungan selayaknya dikaji secara holistik karena aspek afektif juga memerankan peranan yang penting. Dalam perspektif keberlanjutan, perubahan karakter yang bersifat jangka panjang justru dicapai melalui aktivitas afektif seperti keteladanan. Tulisan mengenai keteladanan umumnya mengangkat keteladanan yang diperankan guru atau orang tua (Hidayat, 2015; Munawwaroh, 2019; Sutisna, Indraswati and Sobri, 2019). Berbeda dari tulisan sebelumnya, penelitian ini mengelaborasi bagaimana keteladanan yang diperankan pemimpin sekolah mampu mendorong pelaksanaan program pembiasaan yang mengubah perilaku warga sekolah menengah pertama di Samosir, Sumatera Utara.

Sekolah Menengah Pertama Negeri 2 atau SMPN2 Pangururan terletak di Kecamatan Pangururan, Kabupaten Samosir. Sekolah ini berposisi di tengah Danau Toba yang merupakan salah satu salah satu destinasi super prioritas. Saat ini, permasalahan lingkungan menjadi salah satu isu utama di Samosir dimana pembangunan berkelanjutan yang sedang gencar diwacanakan dihadapkan dengan kurangnya kepedulian masyarakat dalam melestarikan lingkungan (Fransiska dan Suryawan, 2016). SMPN 2 Pangururan sendiri merupakan sekolah yang mampu mengubah karakter siswanya menjadi lebih peduli pada lingkungan. Oleh karena itu penelitian ini bertujuan untuk melihat bagaimana sekolah dapat membentuk karakter peduli lingkungan pada diri siswa untuk mendukung pembangunan berkelanjutan.

Pada bagian hasil dan pembahasan terlebih dahulu dijelaskan mengenai kondisi SMPN2 Pangururan sebelum melaksanakan implementasi pendidikan karakter peduli lingkungan. Kemudian akan dijelaskan temuan mengenai cara SMPN2 Pangururan dalam mengimplementasikan pendidikan karakter peduli lingkungan dan perubahan yang terjadi disekolah. Pada bagian akhir, dipaparkan mengenai analisa dan kesimpulan.

\section{METODE PENELITIAN}

Penelitian ini dilakukan dengan pendekatan kualitatif. Sesuai dengan jenis penelitian yang bersifat kualitatif kehadiran peneliti di lapangan sangat dan diperlukan. Dalam penelitian ini peneliti hadir secara langsung di lapangan untuk mengamati dan mengumpulkan data yang di butuhkankan. Dalam pengumpulan data, penulis melakukan observasi, dokumentasi dan indepth interview atau wawancara mendalam dengan informan sebanyak 9 orang yaitu kepala sekolah, wakil kepala sekolah, wali kelas, guru mata pelajaran, orang tua, dan tiga orang siswa. Waktu yang dibutuhkan dalam penelitian ini berangsung selama dua bulan.

Dalam analisis data, dilakukan reduksi data, penyajian data dan verifikasi data atau penarikan kesimpulan (Sugiyono, 2016). Setiap data yang diperoleh terlebih dahulu dianalisis dengan reduksi data dan memisahkan data yang tidak dibutuhkan. Data kemudian disajikan dalam bentuk tabel untuk mengorganisir. Validitas data penelitian menggunakan metode triangulasi. 
2209 Pendidikan Karakter Peduli Lingkungan Melalui Pembiasaan dan Pembudayaan di Sekolah Menengah Pertama - Lampola Sitorus, Aldi Herindra Lasso

DOI: https://doi.org/10.31004/edukatif.v3i5.755

\section{HASIL DAN PEMBAHASAN PENELITIAN}

\section{Kondisi Lingkungan SMPN 2 Pangururan di Masa Lalu}

SMPN2 Pangururan terletak dipinggir kota Pangururan yang merupakan ibu kota Kabupaten Samosir. Lokasinya cukup strategis yaitu tepat berada di pinggir jalan lintas Samosir. Lokasi yang strategis ini tidak membuat sekolah ini menjadi sekolah favorite, sebaliknya siswa yang mendaftar ke sekolah ini justru rata rata siswa yang tidak diterima disekolah lain karena nilai yang tidak mencukupi. Hal ini pula yang mempengaruhi minimnya prestasi sekolah secara akademik. Sebelum memulai pendidikan karakter peduli lingkungan, SMPN2 Pangururan memiliki lingkungan yang tidak terawat dan cara pengelolaan sekolah yang tidak ramah lingkungan. Kebersihan lingkungan sekolah kurang terjaga dan beberapa fasilitas sekolah tidak difungsikan dengan baik. Kamar mandi tidak terawat dan mengeluarkan bau yang tidak sedap yang mengganggu kenyamanan beraktivitas disekolah. Sehari - hari banyak sampah yang berserakkan dan terdapat tumpukan sampah di beberapa titik sekolah yang dibiarkan begitu saja. "Dulu ada beberapa tumpukan sampah dan kamar mandi kurang bersih jadi aromanya cukup mengganggu", ungkap Ibu Adventri Naibaho yang merupakan seorang guru di SMPN2 Pangururan.

Kondisi ini semakin buruk karena siswa di SMPN2 Pangururan dapat dikatakan memiliki kepedulian lingkungan yang sangat rendah. Para siswa sering membuang sampah secara sembarangan seperti dilapangan, didalam kelas dan dilaci meja. Siswa juga sering bolos dalam melakukan kewajibannya sebagai piket kebersihan. Salah satu hal yang mempengaruhi kondisi perilaku dan sikap siswa ini adalah keteladanan guru sebagai pendidik yang masih rendah. Berdasarkan hasil wawancara dengan kepala sekolah, banyak guru yang sebelumnya kurang peduli dengan kondisi lingkungan sekolah. Hal ini diperkuat dengan pernyataan kepala sekolah dan beberapa guru mengenai adanya tumpukan sampah dibeberapa titik dan kondisi kamar mandi yang tidak terawat sehingga mengeluarkan bau tidak sedap. Hal lain yang menunjukkan tingkat profesionalisme guru yang rendah adalah masih banyak guru yang tidak memiliki perangkat pembelajaran yang lengkap dalam proses belajar mengajar seperti silabus dan RPP.

Pengaruh lainnya datang dari sisi eksternal sekolah dimana beberapa masyarakat sekitar sekolah mengalirkan limbah rumah tangganya ke sekolah. Limbah rumah tangga tersebut berupa limbah kamar mandi, limbah dapur dan limbah dari hasil peternakan seperti ayam dan babi. Manajemen sekolah dan komunikasi yang kurang baik antara sekolah dengan masyarakat serta tanah SMPN2 Pangururan yang merupakan tanah hibah yang dari masyarakat sekitar menjadi salah satu penyebab masyarakat kurang enggan mengalirkan limbah nya ke sekolah. Kondisi sekolah dan warga sekolah yang demikian turut membuat SMPN2 Pangururan menjadi sekolah yang kurang diperhitungkan. Buruknya kondisi SMPN 2 digambarkan oleh kepala sekolah seperti berikut:

"Anak-anak tidak peduli dengan lingkungan sekolah, mereka sering membuang sampah sembarangan termasuk menyimpan sampah dilaci seperti kertas, sampah jajan dan permen karet bekas. Ruang kelas dan kantor itu tidak ditata termasuk juga guru yang kurang maksimal melakukan tugasnya. Dan masih ada guru yang perangkat pembelajarannya tidak lengkap. Jauh sebelum tahun 2017 sekolah kurang diperhitungkan oleh masyarakat sekitar. Dianggap sebagai sekolah yang kurang bagus". (Enny Juliana Naibaho, Percakapan, 4 Desember 2020).

\section{Keteladanan Kepala Sekolah dan Guru Sebagai Pemicu Perubahan}

Proses perubahan SMPN2 Pangururan dari sekolah yang kurang peduli lingkungan menjadi sekolah yang peduli dan berbudaya lingkungan awalnya diinisisasi oleh Ibu Eny Juliana pada tahun 2017. Hal ini bermula saat beliau ditugaskan menjadi kepala SMPN 2 Pangururan oleh Pemerintah Kabupaten Samosir. Selain karena rasa profesionalisme yang tinggi, inisiasi perubahan ini dikarenakan Ibu Enny Juliana menyadari pentingnya kebersihan lingkungan untuk mendukung proses belajar mengajar disekolah.

Dalam pandangan Ibu Enny Juliana Naibaho, menjadi kepala sekolah merupakan amanah dan kepercayaan dan kedua hal ini harus dipertanggungjawabkan. Oleh karena itu, sebagai kepala sekolah, beliau 


\section{Pendidikan Karakter Peduli Lingkungan Melalui Pembiasaan dan Pembudayaan di Sekolah Menengah Pertama - Lampola Sitorus, Aldi Herindra Lasso}

DOI: https://doi.org/10.31004/edukatif.v3i5.755

bertekad harus bisa membawa perubahan yang lebih baik bagi SMPN2 Pangururan. Kepedulian Ibu Enny terhadap lingkungan merupakan hasil didikan keluarga yang sangat peduli dengan kebersihan lingkungan. Kepedulian ini yang kemudian beliau tanamkan di SMPN2 Pangururan. "Orang tua saya sangat peduli dengan kebersihan lingkungan, jadi itu selalu saya terapkan juga termasuk di sekolah ini”, ungkap kepala sekolah.

Kepala sekolah merancang dan menyusun kebijakan serta program yang mendukung keberlanjutan lingkungan. Keberlanjutan lingkungan ini mencakup pengelolaan lingkungan secara fisik maupun pembentukan karakter peduli lingkungan dalam diri guru dan siswa. Beberapa program yang dibuat mencakup pengintegrasian nilai - nilai pendidikan lingkungan hidup kedalam mata pelajaran dan pengembangan budaya sekolah.

Dalam melaksanakan program - program ini, kepala SMPN2 Pangururan menjadikan dirinya sebagai model bagi guru dan siswa. Kepala sekolah memberikan perhatian yang besar terhadap lingkungan sekolah dengan menunjukkan sikap peduli lingkungan dalam kegiatan sehari - hari. Beliau sering membersihkan dan menata kantor serta taman sekolah. Pada awalnya, hal ini dilakukan sendirian bahkan meskipun kadang sudah diluar jam kerja. Kepala sekolah juga membawa beberapa tanaman bunga dari rumah untuk menambah kesan indah di taman sekolah. Dalam beberapa kegiatan, kepala sekolah turut serta dalam merawat sekolah seperti menanam bunga, merawat hutan sekolah dan mendaur ulang sampah. Hal ini juga dilakukan untuk menunjukkan rasa cinta dan kepedulian yang besar terhadap lingkungan sekolah.

Peran lainnya yang ditunjukkan oleh kepala sekolah adalah mengoordinasikan dan mengkomunikasikan inovasi perubahan, rencana, tujuan dan program ke berbagai pihak internal seperti guru, staf dan siswa. Hal ini disampaikan kepada guru dan staf melalui rapat dan pertemuan - pertemuan yang bersifat tidak resmi. Kepala sekolah sering mengadakan rapat non formal bersama guru dan staf untuk menyampaikan hal ini. Beliau juga membangun komunikasi dengan Dinas Lingkungan Hidup Kabupaten Samosir terkait peran sekolah dalam memberikan pendidikan lingkungan hidup. Untuk melibatkan komite sekolah dan orang tua siswa, kepala sekolah mengadakan pertemuan seperti rapat di akhir dan awal tahun ajaran baru. Dalam kegiatan ini, sekolah meyampaikan rencana - rencana inovasi serta mendengarkan aspirasi dari orang tua.

Kepala sekolah menyelaraskan program sekolah dengan dukungan masyarakat. Hal ini dapat dilihat dalam mengatasi limbah domestik masyarakat yang dialirkan ke sekolah. Kepala sekolah menjalin komunikasi dan memberikan pemahaman kepada masyarakat mengenai tujuaan program sekolah dalam mengimpelementasikan pendidikan karakter peduli lingkungan. Kepala sekolah meminta masyarakat agar menghargai keberadaan sekolah sebagai institusi pendidikan dan tidak lagi mengalirkan limbahnya ke sekolah karena hal tersebut menggangu aktivitas. Sekolah kemudian sekolah menutup aliran limbah tersebut. Seorang guru mengatakan:

"Perubahan yang sekarang kita nikmati ini, awalnya dimulai oleh kepala sekolah. Beliau sangat disiplin dengan masalah menjaga lingkungan, dan tidak segan mengutip sampah dan bersih - bersih sendiri. Beliau sering masih berada di sekolah untuk bersih - bersih meski sudah jam pulang sekolah. Jadi kita guru lama lama mengikut juga dengan pimpinan kita dan akhirnya itu jadi kebiasaan kita semua disini. Kita jadi terbiasa membersihkan dan merawat sekolah ini bahkan meski sudah diluar jam kerja." (Adventri Naibaho, Percakapan, 14 Desember 2020).

Untuk mempermudah koordinasi kerja guru, kepala sekolah membagi guru kedalam beberapa kelompak kerja atau pokja. Pokja ini terdiri dari pokja pengembang kurikulum, taman, bank sampah dan jumat bersih, publikasi, green house dan pembibitan, 4R (reduce, recycle, reuse, repair), biopori, komposting, kebersihan lingkungan dan kamar mandi, kantin sehat dan boga. Pokja ini kemudian bekerja sesuai tugas dan tanggungjawab masing-masing dan bertanggungjawab kepada kepala sekolah.

Salah satu tantangan yang ditemui oleh kepala sekolah dalam membentuk karakter adalah rasa kekompakan dan kekeluargaan yang rendah pada tataran guru yang mempengaruhi kinerja guru. Untuk itu kepala sekolah sering mengadakan pertemuan yang bersifat santai dan tidak resmi. Kepala sekolah sering 


\section{Pendidikan Karakter Peduli Lingkungan Melalui Pembiasaan dan Pembudayaan di Sekolah Menengah Pertama - Lampola Sitorus, Aldi Herindra Lasso}

DOI: https://doi.org/10.31004/edukatif.v3i5.755

mengajak guru untuk quality time bersama seperti minum kopi bersama, karaoke bersama, makan bersama dan olahraga bersama. Kegiatan seperti ini bertujuan untuk meningkatkan rasa kekompakan dan kekeluargaan ditataran guru dan staf. Selain untuk membentuk rasa kekeluargaan dalam berbagai pertemuan ini kepala sekolah juga sering menyampaikan inovasi-inovasi yang akan dilakukan sekolah sekaligus mendengarkan aspirasi para guru dengan suasana yang lebih santai.

Rasa kecintaan guru terhadap sekolah juga rendah sehingga membuat guru cenderung kurang maksimal dalam melaksanakan tugasnya. Untuk mengatasi hal ini, kepala sekolah selalu membangun narasi di tataran guru dan staf bahwa SMPN2 Pangururan adalah rumah kedua bagi mereka. Rasa peduli terhadap sekolah haruslah sebesar rasa peduli terhadap rumah masing - masing. Perubahan SMPN2 Pangururan menjadi sekolah yang peduli dan berbudaya lingkungan sangat dipengaruhi oleh kepemimpinan kepala sekolah. Keteladanan yang diberikan kepala SMPN 2 Pangururan telah berhasil mengubah kinerja dan menggugah karakter peduli lingkungan di kalangan guru-guru SMPN 2 Pangruran. Hal ini mengkonfirmasi pemikiran bahwa seorang pemimpin dengan kepercayaan diri, kemampuan bersosialisasi, beradaptasi, dan bekerjasama yang baik mampu menginspirasi jajarannya untuk meneladaninya (Spillane, Halverson and Diamond, 2004).

Sebagai pendidik kepala sekolah, guru dan pegawai SMPN2 Pangururan telah menjadi teladan bagi para siswa dalam membentuk karakter peduli lingkungan. Keteladanan ini sesuai dengan peran guru sebagai teladan, model, dan mentor bagi siswa (Wardani, 2010). Keteladanan ditunjukkan mulai dari kepala sekolah, guru dan staf. Keteladanan kepala sekolah ditunjukkan melalui disiplin dan militansi dalam kepemimpinannya seperti dijelaskan di sub bab Peran Kepala Sekolah. Keteladanan ini dapat dilihat dari sikap guru yang selalu menjaga kebersihan dengan membuang sampah pada tempatnya dan keterlibatan guru dalam mengelola lingkungan sekolah. Guru di SMPN2 Pangururan guru juga turut serta dalam mengutip sampah, membersihkan sekolah dan menata taman. Dalam kegiatan jumat bersih, guru turut serta menanam bunga dan menata taman. Dalam pengelolaan sampah, guru juga turun tangan secara langsung dengan ikut melakukan pengomposan dan membuat kerajinan tangan bersama - sama dengan siswa. Keteladanan lainnya adalah guru tidak merokok didalam kelas atau pada saat melakukan aktivitas mengajar. Berikut pernyataan narasumber yang merupakan seorang siswa kepada peneliti:

"Sehari-harinya kepala sekolah dan bapak ibu guru juga ikut mengutip sampah dan bergotong royong menanam bunga. Jadi kalau lagi kegiatan gotong royong kita sama - sama menanam bunga dan sayur - sayur an. Membuat kompos dan pohon natal dari botol minuman bekas juga kita lakukan bersama - sama dengan guru" (Ferdinan, Percakapan, 6 Januari 2020).

Dalam kajian mengenai pendidikan karakter peduli lingkungan, peran kepala sekolah melalui kepemimpinan dan keteladanannya jarang mendapat sorotan (Khairoh, Rusilowati dan Nurhayati, 2014; Ariyani dan Wangid, 2016; Rezkita dan Wardani, 2018). Padahal kasus di SMPN 2 Pangururan menunjukkan pemimpin menjadi faktor penting dalam keberhasilan atau kegagalan penerapan pendidikan karakter peduli lingkungan. Keteladanan dari kepala sekolah ini menjadi faktor penting yang mampu membawa perubahan karakter pada warga sekolah. Kasus SMPN 2 Pangururan ini menunjukkan bahwa keteladan dalam pendidikan karakter peduli lingkungan bukan hanya terjadi antara guru dan murid atau orang tua dan anak saja tetapi antara pimpinan yang mampu mengubah bawahannya untuk kemudian memberikan teladan kepada siswanya. Sejatinya, program kepedulian lingkungan bisa saja dilakukan oleh semua sekolah demi menjalankan tugas sekolah dalam membentuk karakter peduli lingkungan. Tetapi tanpa keteladanan, program ini tidak dapat berjalan dengan maksimal dan menyentuh esensinya. Program yang dilakukan oleh SMPN2 Pangururan dapat berjalan dengan baik dan berkelanjutan karena ada sosok yang digugu oleh semua warga sekolah yaitu kepala sekolah melalui keteladan yang diberikan.

Temuan ini menegaskan bahwa kepala sekolah berperan penting dalam menyukseskan pendidikan karakter (Mulyasa, 2018 : 67). Kasus SMPN2 Pangururan juga menunjukkan bahwa peranan pemimpin sekolah mampu mengubah tidak hanya karakter peduli lingkungan saja tetapi juga mengubah gambaran 


\section{Pendidikan Karakter Peduli Lingkungan Melalui Pembiasaan dan Pembudayaan di Sekolah Menengah Pertama - Lampola Sitorus, Aldi Herindra Lasso}

DOI: https://doi.org/10.31004/edukatif.v3i5.755

SMPN2 Pangururan sebagai sekolah yang sebelumnya kurang diperhitungan dan tidak peduli lingkungan menjadi salah satu sekolah panutan dalam penerapan pendidikan karakter peduli lingkungan di Kabupaten Samosir. Hal ini sesuai dengan temua (Fitrah, 2017) bahwa sekolah berkualitas atau tidak sangat bergantung pada pola kepemimpinan kepala sekolah. Peranan yang dimainkan oleh kepala sekolah menunjukkan salah satu implementasi pendidikan peduli lingkungan yaitu keteladanan.

\section{Kegiatan Pembentuk Budaya Peduli Lingkungan yang Dipicu Keteladanan}

Pendidikan karakter peduli lingkungan dapat diterapkan dalam Mata Pelajaran melalui Rencana Pelaksanaan Pembelajaran (RPP) dan silabus; integrasi dalam muatan lokal; kegiatan pengembangan diri berupa pembudayaan dan pembiasaan ektstrakurikuler; bimbingan konseling (Kementerian Pendidikan Nasional, 2011; Purwanti, 2017). Walaupun SMPN 2 Pangururan telah melakukan implementasi pendidikan karakter peduli lingkungan melalui integrasi kedalam silabus dan Rencana Pelaksanaan Pendidikan, penerapan Pendidikan peduli lingkungan banyak dilaksanakan melalui pembiasaan dan pembudayaan peduli lingkungan. Muara dari proses pendidikan adalah perubahan tingkah laku peserta didik menjadi lebih baik lagi (Marisyah, Firman and Rusdinal, 2019). Oleh karena itu dalam membentuk karakter peduli lingkungan, pemahaman atau pengetahuan mengenai lingkungan tidak lah cukup tetapi harus dibarengi dengan pembentukan kebiasaan atau tingkah laku. Dalam kasus SMPN 2, dampak pendidikan karakter peduli lingkungan justru banyak terlihat dalam kegiatan pengembangan diri yang terdiri dari pengembangan pembiasaan diri dan pengembangan budaya sekolah.

Keteladanan yang diberikan oleh kepala sekolah dan guru telah memicu kemunculan kegiatan-kegiatan pembiasaan dan pembudayaan peduli lingkungan. Untuk membentuk dan menguatkan kepedulian siswa dan guru terhadap lingkungan, SMPN2 membuat beberapa kegiatan yang dilakukan secara rutin atau terus menerus dan bersifat konsisten dan kegiatan yang bersifat spontan. Diantaranya adalah kebersihan harian, program LISA, kebersihan mingguan dan kegiatan 3R (reduce, recycle, reuse). Selain kegiatan rutin, ada juga beberapa kegiatan yang bersifat spontan seperti teguran yang dilakukan diantara sesama guru maupun teguran yang diberolam guru kepada siswa.

Untuk menjaga kebersihan sekolah setiap hari, guru menyusun piket kebersihan harian yang terdiri dari siswa. Piket ini bertugas untuk memberihkan ruang kelas pada siang hari sepulang jam sekolah dan mengelap meja dan jendela pada pagi hari sebelum memulai kelas. Setiap pagi mulai dari siswa memasuki gerbang sekolah, siswa dibiasakan untuk memperhatikan kondisi kebersihan lingkungan sekitarnya. Apabila ada sampah yang terletak tidak pada tempatnya, maka siswa wajib memungut dan membuang ke tempat sampah. Untuk menguatkan kebiasaan ini, sekolah juga menerapkan program LISA (Lihat Sampah Ambil Buang) dalam setiap kegiatan sekolah. Melalui kegiatan ini, setiap siswa dan guru diwajibkan memungut sampah yang terletak tidak pada tempatnya kemudian membuangnya ke tempat sampah. Harapan sekolah adalah kebiasaan ini menjadi budaya bagi semua warga sekolah dimanapun berada.

Dalam hal kebersihan mingguan, SMPN 2 Pangururan mengadakan kegiatan Jumat bersih yang dilakukan setiap hari Jumat. Kegiatannya berupa membersihkan seluruh pekarangan sekolah, menata ruang kelas, taman depan kelas, hutan sekolah dan mengelola sampah. Dalam kegiatan Jumat bersih ini, sekolah menerapkan program 3R (reduce, recycle, reuse). Dalam kegiatan reduce, sekolah mengurangi penggunaan plastik dengan menyediakan galon air minum di setiap kelas. Hal ini untuk mengurangi penggunaan plastik melalui air mineral kemasan. Selain itu, sekolah juga melarang penjualan makanan berbungkus plastik di kantin sekolah. Dalam rangka reuse sekolah menggunakan kembali barang - barang bekas seperti kaleng cat bekas, ember bekas, ban bekas dan botol minum plastik sekali pakai. Barang ini digunakan kembali menjadi keranjang sampah dan pot bunga. Dalam rangka recycle, sekolah melakukan daur ulang sampah organik dan non organik. Sekolah mengelola sampah organik menjadi pupuk dan kompos. Sementara sampah nonorganik seperti plastik didaur ulang menjadi kerajinan tangan. Contohnya adalah bunga meja, pohon natal dan hiasan dinding. 


\section{Pendidikan Karakter Peduli Lingkungan Melalui Pembiasaan dan Pembudayaan di Sekolah Menengah Pertama - Lampola Sitorus, Aldi Herindra Lasso}

DOI: https://doi.org/10.31004/edukatif.v3i5.755

Sampah atau barang - barang yang didaur ulang oleh sekolah tidak hanya berasal dari lingkungan sekolah tetapi juga dari lingkungan masyarakat termasuk sampah dari pinggir jalan yang dikutip oleh siswa. Ketika sekolah hendak melakukan daur ulang sampah pada hari Jumat, maka siswa akan diminta mengumpulkan sampah - sampah plastik, kaleng dan ban bekas dari lingkungan masing - masing. Selain untuk mengurangi jumlah sampah, hal ini juga bertujuan untuk memberikan edukasi kepada masyarakat.

Dalam kegiatan sehari - hari SMPN 2 juga dilakukan melaui kegiatan yang bersifat spontan diantaranya berupa ajakan, teguran, hukuman dan reward. Guru selalu mengajak siswa untuk membuang sampah pada tempatnya dan mengutip sampah yang terletak tidak pada tempatnya. Ketika guru melihat siswa membuang sampah tidak pada tempatnya atau bersikap cuek ketika melihat lingkungan dalam kondisi kotor, maka akan diberikan teguran dan hukuman secara langsung berupa membersihkan sekolah diluar jadwal piket. "Saya pernah dihukum guru karena kedapatan membuang sampah kertas dihalaman. Saya dinasehati kemudian disuruh menyapu halaman" (Airin Bakkara, Percakapan, 6 Desember 2020).

Dalam pengimplementasian pendidikan karakter peduli lingkungan, SMPN 2 Pangururan juga membuat beberapa kegiatan terprogram yang dilakukan dalam jangka waktu tertentu. Misalnya dalam menyambut penghujung semester dan hari - hari besar nasional seperti Perayaan Kemerdekaan 17 Agustus dan Hari Guru sekolah mengadakan kegiatan yang bertujuan untuk meningkatkan kepedulian warga sekolah terhadap lingkungan. Kegiatan yang dilakukan seperti lomba kebersihan per kelas, lomba kreasi taman, lomba kreasi menggunakan daur ulang sampah, lomba literasi lingkungan, serta lomba puisi dan karya ilmiah dengan tema lingkungan. Dalam menyambut hari - hari besar ini, sekolah juga melakukan kebersihan di jalan besar Pangururan. Berbagai kegiatan ini dapat meningkatkan motivasi dan kepekaan siswa dalam merawat lingkungan dan memberikan contoh peduli lingkungan kepada masyarakat. Bagi kelas yang memenangkan perlombaan akan diberikan hadiah berupa uang yang kemudian diguakan untuk menghias kelas sesuai dengan kreatifitas siswa.

Selain perlombaan, kegiatan terprogram lainnya adalah pada saat penerimaan siswa baru SMPN2 Pangururan akan mengadakan MPLS (Masa Perkenalan Lingkungan Sekolah). Pada kegiatan ini, siswa akan diajak untuk mengenal SMPN2 termasuk cara sekolah dalam mengelola lingkungan. Guru akan memberikan pembinaan kepada siswa baru agar menjaga lingkungan sekolah. Jenis kegiatan yang dilakukan adalah memberikan wawasan lingkungan terutama lingkungan danau Toba yang disampaikan langsung oleh aktivis lingkungan. Sekolah akan menyampaikan jenis - jenis kegiatan yang dilakukan sekolah dalam rangka mengelola lingkungan. Selain itu siswa baru juga akan diarahkan untuk menciptakan sebuah karya dengan mendaur ulang barang bekas yang dipungut dari lokasi luar sekolah. Cara SMPN2 Pangururan dalam mengelola lingkungan menunjukkan bahwa sekolah dapat menjadi model dalam mewujudkan lingkungan yang sehat dan nyaman hal ini sesuai dengan penelitian yang dilakukan oleh (Desfandi, 2015).

Untuk memaksimalkan pembentukan karakter, sekolah melibatkan komite sekolah dan orang tua siswa. Keterlibatan ini terlihat dari berbagai event yang diadakan sekolah dengan mengundang orang tua. Dalam moment tertentu seperti tahun baru, sekolah mengadakan syukuran bersama orang tua sekaligus mengadakan pameran. Syukuran ini diadakan untuk mempererat tali silaturahmi antara sekolah dengan orang tua dan komite sekolah. Dalam pameran ini, sekolah menunjukkan karya siswa dari hasil ulang barang bekas. Selain itu sekolah juga mengadakan rapat bersama komite dan orang tua yang biasanya dilakukan pada akhir semester untuk menyampaikan program yang telah dilaksanakan, sedang dilaksanakan dan akan dilaksanakan. Dalam rapat ini sekolah juga menyampaikan kondisi siswa dan mengajak orang tua agar menyelaraskan budaya sekolah dengan budaya dirumah dalam hal pengelolaan lingkungan. Hal ini penting karena dalam penguatan karakter, sekolah harus dapat memaksimalkan peran orang tua (Wulandari and Kristiawan, 2017), mengingat para siswa lebih banyak menghabiskan waktunya di rumah dimana peran orang tua menjadi penting. 


\section{Pendidikan Karakter Peduli Lingkungan Melalui Pembiasaan dan Pembudayaan di Sekolah Menengah Pertama - Lampola Sitorus, Aldi Herindra Lasso}

DOI: https://doi.org/10.31004/edukatif.v3i5.755

\section{Fasilitas Pendukung Pembentukan Budaya Peduli Lingkungan}

SMPN2 Pangururan melengkapi fasilitas pendukung kebersihan seperti tempat sampah yang terbuat dari barang bekas. Sekolah menyediakan tempat sampah terpisah antara sampah organik dan anorganik. Selain itu, sekolah juga menyediakan peralatan kebersihan seperti sapu, kain pel, kemoceng dan ember. Dibeberapa titik sekolah menempelkan slogan yang berisi anjuran untuk mengelola lingkungan dengan baik dan penghematan energi. Beberapa anjuran seperti matikan kran kalau air sudah penuh; gunakan listrik seperlunya.

Selain penyediaan tempat sampah, pihak sekolah membuat hutan sekolah yang terletak dibelakang sekolah. Hutan sekolah ini dibuat dengan memanfaatkan lahan kosong yang sebelumnya tidak dikelola. Hutan ini ditanami berbagai jenis tanaman seperti pohon jambu, rempah-rempah, sayur-sayuran dan tanaman hias. Area ini dimanfaatkan sebagai salah satu area edukasi pemanfaatan lahan kosong menjadi lahan produktif.

Sekolah juga menata taman dengan rapi dan bersih sehingga dapat mendukung kenyamanan siswa dan guru dalam beraktivitas. Taman ini ditanami dengan beberapa jenis tumbuhan seperti bunga dan bawang bawangan. Selain taman yang terletak didepan masing - masing ruangan, sekolah membuat taman gantung yang terletak dibeberapa lokasi sekolah seperti di dinding dan dipohon sekolah. Taman ini sangat menambah nilai estetika sekolah. SMPN2 Pangururan juga memiliki green house sekolah yang terdiri dari sebuah bangunan yang terbuat dari kayu yang diisi dengan tanaman bunga dan tanaman bawang --bawangan. Semua pot yang digunakan dalam hutan sekolah, taman sekolah dan green house merupakan pot hasil daur ulang barang bekas. Begitu juga dengan kompos yang digunakan merupakan hasil pengolahan sampah organik. SMPN2 Pangururan memiliki beberapa biopori yang terletak dibeberapa titik sekolah. Tujuannya adalah menambah daya resap tanah terhadap air. Biopori ini dibuat oleh siswa dengan dampingan guru.

Pendidikan karakter peduli lingkungan juga dilakukan dengan Penyediaan fasilitas pendukung yang tidak secara langsung berhubungan dengan lingkungan tetapi pesan pendidikan peduli lingkungan tetap tersampaikan. Sekolah membuat kantin sehat yang menjajakan makanan yang bebas dari bungkus plastik, bebas pewarna dan pengawet. Jajanan yang dijual dimasak dirumah terlebih dahulu agar sekolah tidak terganggu dengan proses masak memasak jajanan. Hal ini dilakukan untuk mengurangi limbah rumah tangga yang bisa ditimbulkan jika proses memasak dilakukan di kantin tersebut.

Penyediaan fasilitas pendukung ini telah menghasilkan terjadinya perubahan fisik dimana sekolah menjadi lebih indah dan lebih bersih. Fasilitas sekolah berfungsi dan terawat dengan baik seperti kamar mandi yang tidak lagi mengeluarkan aroma kurang sedap, lahan kosong difungsikan menjadi taman, hutan sekolah dan tempat pengomposan. Tidak terdapat tumpukan atau timbunan sampah dilokasi sekolah. Kamar mandi yang rusak dirombak dan dijadikan sebagai lokasi taman gantung. Tampilan sekolah menjadi semakin estetik dengan pajangan pot hasil daur ulang sampah yang dihias oleh siswa dan guru. Sekolah menjadi tempat yang nyaman bagi guru dan siswa untuk melakukan aktivitas.

Melalui penelitian ini dapat dilihat peran sekolah dalam mendukung pembangunan berkelanjutan terlihat dalam dua bagian yaitu membentuk manusia yang peduli lingkungan dan mengurangi jumlah sampah melalui program pengelolaan lingkungan. Dalam menjalankan peran ini, kepemimpinan dan keteladanan kepala sekolah menjadi faktor utama yang menyukses kan program kepedulian lingkungan. Keteladanan terbagi dalam dua tahap yaitu keteladanan kepala sekolah yang menginspirasi dan ditiru oleh para guru kemudian keteladanan ini ditunjukkan dan dilanjutkan oleh guru dalam mendidik siswa.

Hal yang perlu menjadi perhatian adalah keselarasan budaya sekolah dengan budaya di rumah masing masing siswa. Selain membawa pengaruh positif ke lingkungan masyakarat, kebiasaan baik yang sudah ditanamkan disekolah juga terpengaruh oleh kebiasaan dirumah. Untuk itu diperlukan kerjasama dan komunikasi yang intens antara sekolah dengan orang tua siswa untuk menyelaraskan pembiasaan. Mengenai keselarasan antara budaya dirumah dengan budaya disekolah menjadi keterbatasan dalam penelitian ini dan perlu dilakukan penelitian lebih lanjut. 
2215 Pendidikan Karakter Peduli Lingkungan Melalui Pembiasaan dan Pembudayaan di Sekolah Menengah Pertama - Lampola Sitorus, Aldi Herindra Lasso

DOI: https://doi.org/10.31004/edukatif.v3i5.755

\section{KESIMPULAN}

Hasil penelitian menunjukkan bahwa sekolah dapat berperan besar dalam mendukung pembangunan yang keberlanjutan. Dari Kasus di SMPN 2 Pangururan, implementasi pendidikan karakter peduli lingkungan telah dilakukan sesuai dengan yang direkomendasikan oleh Kementerian Pendidikan Nasional. Namun penerapan yang paling menonjol adalah penerapan melalui pembiasaan dan pembudayaan yang berhasil dibentuk dengan dukungan faktor keteladanan. Keteladanan yang diberikan pemimpin sekolah kepada para guru telah berhasil mengubah karakter guru untuk kemudian menjadi teladan bagi para siswa. Keteladanan ini juga yang mendorong kegiatan-kegiatan pembiasaan di SMPN 2 Pangururan. Dengan latar belakang kemampuan akademis menengah, siswa SMPN 2 Pangururan menunjukkan bahwa tingkat kognitif yang tinggi tidak menjamin keberhasilan pendidikan karakter peduli lingkungan. Sebagai rekomendasi, pendidikan karakter peduli lingkungan sangat penting diimplementasikan oleh semua sekolah termasuk sekolah di Kabupaten Samosir. Mengingat pentingnya peranan pemimpin dalam penerapan pendidikan karakter peduli lingkungan, pemilihan kepala sekolah yang memiliki kemampuan dan kredibilitas yang baik menjadi hal yang perlu diprioritaskan.

\section{DAFTAR PUSTAKA}

Afandi, R. (2013). Integrasi Pendidikan Lingkungan Hidup Melalui Pembelajaran IPS Di Sekolah Dasar Sebagai Alternatif Menciptakan Sekolah Hijau. Pedagogia: Jurnal Pendidikan 2(1): 98-108.

Ariyani, Y. D., \& Wangid, M. N. (2016). Pengembangan Bahan Ajar Tematik-Integratif Berbasis Nilai Karakter Peduli Lingkungan Dan Tanggung Jawab. Jurnal Pendidikan Karakter 6(1): 116-129.

Chen, X., Huang, B., \& Lin, C. Te. (2019). Environmental Awareness And Environmental Kuznets Curve. Economic Modelling 77(1): 2-11.

Desfandi, M. (2015). Mewujudkan Masyarakat Berkarakter Peduli Lingkungan Melalui Program Adiwiyata. Sosio Didaktika: Social Science Education Journal 2(1): 31-37.

Fitrah, M. (2017). Peran Kepala Sekolah Dalam Meningkatkan Mutu Pendidikan. Jurnal Penjaminan Mutu 3(1): $31-42$.

Fransiska, \& Suryawan, I. B. (2016). Strategi Pengelolaan Kabupaten Samosir Sebagai Daya Tarik Wisata Alam Di Provinsi Sumatera Utara. 4(1): 14-19.

Hidayat, N. (2015). Metode Keteladanan Dalam Pendidikan Islam', Ta'allum: Jurnal Pendidikan Islam 3(2): $135-150$.

Juanda. (2010). Peranan Pendidikan Formal Dalam Proses Pembudayaan. Lentera Pendidikan : Jurnal Ilmu Tarbiyah Dan Keguruan 13(1): 1-15.

Kementerian Pendidikan Nasional. (2011). Panduan Pelaksanaan Pendidikan Karakter [Guideline On The Implementation Of Character Education]. In Guideline.

Khairoh, L., Rusilowati, A., \& Nurhayati, S. (2014). Pengembangan Buku Cerita IPA Terpadu Bermuatan Pendidikan Karakter Peduli Lingkungan Pada Tema Pencemaran Lingkungan. Unnes Science Education Journal 3(2): 519-527.

Kurniawan, W. (2015). Dampak Sosial Ekonomi Pembangunan Pariwisata Umbul Sidomukti Kecamatan Bandungan Kabupaten Semarang. Economics Development Analysis Journal 4(4): 443-451.

Lulus, R., Nss, P., Suryawardana, E., \& Triyani, D. (2015). Analisis Dampak Pembangunan Infrastruktur Jalan Terhadap Pertumbuhan Usaha Ekonomi Rakyat Di Kota Semarang. Jurnal Dinamika Sosial Budaya 17(1): 82-103.

Marisyah, A., Firman, \& Rusdinal. (2019). Pemikiran Ki Hadjar Dewantara Tentang Pendidikan 33(11): 2- 
2216 Pendidikan Karakter Peduli Lingkungan Melalui Pembiasaan dan Pembudayaan di Sekolah Menengah Pertama - Lampola Sitorus, Aldi Herindra Lasso

DOI: https://doi.org/10.31004/edukatif.v3i5.755

6.

Miranto, S. (2017). Integrasi Konsep-Konsep Pendidikan Lingkungan Hidup Dalam Pembelajaran Di Sekolah Menengah. Edusains 9(1): 81-88.

Mulyasa, H. E. (2018). Manajemen Pendidikan Karakter (1st Ed.; Dewi Ispurwanti, Ed.). Jakarta: Bumi Aksara.

Munawwaroh, A. (2019). Keteladanan Sebagai Metode Pendidikan Karakter', Jurnal Penelitian Pendidikan Islam 7(2): 141-156.

Ozsoy, S., Ertepinar, H., \& Saglam, N. (2012). Can Eco-Schools Improve Elementary School Students' Environmental Literacy Levels? Asia-Pacific Forum On Science Learning And Teaching, 13(2): 1-25.

Prasetiyo, W. H. And Suyanto, T. (2013) Strategi Pendidikan Karakter Peduli Lingkungan Melalui Program Kampung Hijau Di Kampung Margorukun Surabaya, Kajian Moral Dan Kewarganegaraan, 2(1): 302-316.

Purwanti, D. (2017). Pendidikan Karakter Peduli Lingkungan Dan Implementasinya 1(2): 14-20

Puspitasari, R. (2016), Penanaman Nilai Karakter Peduli Lingkungan Dalam Muatan Environmental Education Pada Pembelajaran IPS Di MI Darul Hikam Kota Cirebon, Al Ibtida: Jurnal Pendidikan Guru MI, 3(1)

Rezkita, S., \& Wardani, K. (2018). Pengintegrasian Pendidikan Lingkungan Hidup Membentuk Karakter Peduli Lingkungan Di Sekolah Dasar. Trihayu 4(2): 327-331.

Rokhman, F., Hum, M., Syaifudin, A., \& Yuliati. (2014). Character Education For Golden Generation 2045 (National Character Building For Indonesian Golden Years). Procedia - Social And Behavioral Sciences 141(1): 1161-1165.

Sarbi, S. (2018). Kerusakan Hutan Dan Lingkugan Hidup Dari Pembangunan Dan Pertumbuhan Penduduk (Studi Kasus Di Kabupaten Polewali Mandar). Pepatudzu: Media Pendidikan Dan Sosial Kemasyarakatan 13(2): 193.

Setiyani, N. (2013) Pendidikan Karakter Peduli Lingkungan Melalui Program "Green Environment" Di Smp Alam Ar-Ridho Kota Semarang. Universitas Negeri Semarang.

Spillane, J. P., Halverson, R., \& Diamond, J. B. (2004). Towards A Theory Of Leadership Practice: A Distributed Perspective. Journal Of Curriculum Studies, 36(1): 3-34.

Sugiyono. (2016). Metode Penelitian Kuantitatif, Kualitatif, Dan R@D. Bandung: Alfabeta.

Sutisna, D., Indraswati, D. And Sobri, M. (2019) Keteladanan Guru Sebagai Sarana Penerapan Pendidikan Karakter Siswa, JPDI (Jurnal Pendidikan Dasar Indonesia), 4(2): 29-33.

Wardani, K. (2010). Peran Guru Dalam Pendidikan Karakter Menurut Konsep Pendidikan Ki Hadjar Dewantara. Hal 8-10.

Widianingsih, W. (2019) Implementasi Nilai Karakter Peduli Lingkungan Pada Mata Pelajaran IPS Terpadu Siswa Kelas VIII SMP Negeri 3 Pringgarata Tahun Pelajaran 2019/2020, UIN Mataram

Wulandari, Y., \& Kristiawan, M. (2017). Strategi Sekolah Dalam Penguatan Pendidikan Karakter Bagi Siswa Dengan Memaksimalkan Peran Orang Tua. JMKSP (Jurnal Manajemen, Kepemimpinan, Dan Supervisi Pendidikan) 2(2) : 290-303.

Zebua, M. T. (2017). Kajian Dampak Kerusakan Lingkungan Akibat Aktifitas Bermukim Di Kelurahan Bhayangkara Distrik Jayapura Utara. Dinamis, 2(12): 28-37. Tersedia Pada: Http://Ojs.Ustj.Ac.Id/Dinamis/Article/View/10. 